\title{
The Economic Literacy Education For Elementary School Students
}

\author{
Dr. Nunung Nurastuti Utami, SE, MSi ${ }^{1}$ \\ ${ }^{I}$ Malangkucecwara College of Economics, Indonesia
}

\begin{abstract}
The economic literacy learning not only for adults but since they are small because early learning for economic literacy encourage a sense pattern how to choice a good opportunity in young until adults and to control a mental attitude for future financial goals. This learning will be help a person more clear in his mind what to do and should be done for short and long term goals.

The aim of the study is to describe portrait the implementation of the economic literacy learning in elementary school and the what they needs. The results of research through in-dept interview and gives quetionnaire for the social science teachers in $3^{\text {rd }}, 4^{\text {th }}, 5^{\text {th }}$ and $6^{\text {th }}$ level for eight elementary schools in Malang - Indonesia are: 1) The economic literacy learning on elementary school has not been done in detail content, and language was conventional, because the material has not been fueled economic literacy and put a little part of social science material and its presentation is less attractive becouse its language is formal. 2). Elementary school teachers agree that economic literacy learning is given detail, they are ready even though it is undeniable still requires preparation and they have no reservations for the future of the students.

The real condition, the elementary school requires the economic literacy books that uses easy language, attractive and fun, they needs books of economic literacy bases cartoons, so the student pleased to learn and embeded in mind since childhood, so they have the character of behavior economically, so that their life later prosperous.
\end{abstract}

Key Word : Learning - economic literacy - elementary school.

\section{Introduction}

Economic literacy is inseparable from human life, because it affects the quality of decisions in achieving prosperity on the life each person. The economic literacy will make individuals become a smart consumers, the economic literacy education is expected to improve the ability of consumers to protect themselves from business practices that harm consumers, to be able to improve their welfare. Education of consumers is expected to increase consumer awareness to avoid or reduce consumption of products that endanger themselves and or others.

The economic literacy education is required early age because economic literacy plays an important role to trigger self control to manage limited resources. Restraint that will also affect the mental attitude to be more focused on the future financial goals. Self control is directed at a specific goal will be easier because it helps someone realized more clear in his mind what to do and what should be done and what should be avoided with respect to achieving short term, medium and long term goals. Making a smart economic decision is a choice, and this choice requires effort. Besides the individual efforts they also need to understand the terms of the right to make economic decisions daily. Related efforts and the requirements of the economic literacy better be a choice that a person has.

Matsuura found that economic literacy not only involves thinking and reading skills, but for the process of learning and life skills that will be used by humans, a community or a nation to survive and continually changing. In other words, without the economic literacy, the nation, or the human community will be difficult to make sure to survive appropriate as a human being. Not much different according to the Collins Dictionary and Thesaurus that literacy means the ability to read, write, education, learning and knowledge (Gouws \& Shouttleworth. 2009).

Yunus, Isaac \& Jalil (2010) says that economic literacy is the knowledge and teachers expertise to manage expenses, savings, investment and awareness of financial information. Other researchers Mathews (1999) found that economic literacy is the ability of individuals to identify and use traditional economic concepts and ways of thinking to improve the economy and get welfare. In Molem (2007) that economic literacy is an individual who has an understanding of personal financial economics that drive be informed and understand public policy. In this study, using the definition explicitly emphasizes the concepts and how to think properly.

Jappeli (2010) stated that economic literacy is very important for households to make decisions about how do right invest, how much right to borrow on the money market, and how to understand the consequences 
on the overall stability of the economy.

Kotte and Witt (2011) explained that economic literacy becomes something that must be owned by someone because of economic literacy would make someone become more informed. It means that economic literacy would encourage someone to have the ability to analyze and integrate information that can be utilized to make the right financial decisions.

Joseph Cornell, a famous natural educator with the natural development of the game in the very understanding on psychology. In 1979 he developed the concept flow learning several activities or games to be constructed that synchronizes the learning process in the mind, senses and motion. He designed such that the emotional state of the child is best at the time to accept the things that are important in learning. Based on the results of research in Indonesia literacy has no effect on economic growth in Indonesia, it is presumably because the effect of economic literacy is not close to economic growth, but the effect is economic literacy is close to economic growth. (Utami, Nunung N: 2011).

Results of research on entrepreneurs behavior of coastal regions of South Malang East Java Indonesia, that education has no effect on entrepreneurs behavior as a thorough education of respondents and non-formal education is an education formal are not related to economic activities they pursue, it does give an indication they need education relating to economic activities in order to improve their businesses. (Utami, Nunung N: 2008).

Personal characteristic that is significant but negative effect of education on independence of business of urban poor communities (Utami, Nunung: 2007), for example: the higher education the lower the independence of its business, it means that of urban poor communities need education related to their business and they are not familiar with economic education to increase their efforts.

In essence, the economic literacy education is a field of study that is given for the benefit of formal education, informal and non-formal. In formal education at the elementary level, economic literacy education aims to prepare students for a generation of people that have: (1) knowledge of economics both theoretically and practically; (2) critical and rational attitude in any economic phenomenon related to community and economic activity related to government policy, and (3) practical skills to analyze or link the theory to economic phenomena according with the demands of development of the era, both in the local context, national, and international (Wahjoedi, 2008).

\section{Research Of Problem}

According to the background of the problems described above, the general problem of this study is: how the portrait and needs of economic literacy materials for primary school children and how to develop or create and implement economic literacy education with a cartoon image format that is easy to understand and fun to learn for elementary school children.

\section{Methods}

This research is the development research of economic literacy learning for elementary students with the cartoons based format, in other words that the results of this study are expected to be obtained teaching materials will be favored economic literacy of primary school students so that the material can be easily absorbed by elementary school students, and will be faithful to the memory them, so it can be applied to everyday life and long run impact on the future life.

\subsection{Instructional of development research procedures performed in this study are as follows:}

a) Development research of economic literacy education learning for elementary students with cartoons based format on the exploration of teaching practices of economic literacy education for elementary students. To obtain optimal development of learning outcomes will be validated by experts in learning and economics

b) The Implementation of trial results for elementary school students in the city of Malang, Indonesia. The trial results are used to revise and refinement to produce of economic literacy learning to be adaptive according to the real conditions in elementary school. c) Dissemination of the model will be made for elementary school social studies teachers to attention to local knowledge.

\subsection{The Samples}

This research was conducted in public and private elementary school in the Malang city - Indonesia, where the purpose of this study was taken a purposive sample using cluster random sampling technique. Cluster grouping is based on the consideration that the characteristics of each sample of 4 schools, so in total there are 8 were observed namely: SDN Blimbing 3 , SDN Tunjung Sekar, , MIN Malang 1, SDN Muhammadiyah 
Mojolangu. Private : SD Islam Sabilillah, SD Insan Amanah, SD Plus Alkautsar dan SD Muhammadiyah Mojolangu.

\section{Result}

\section{Result And Discussion.}

The results of a survey for teachers who teach social studies on the implementation of character education shows that all social studies teachers know the meaning of economic literacy, this is because the education department has socialized character education to all teachers, $75 \%$ of them claimed to have implemented character education materials economy, but its application is not programmed to use a good lesson plan. Statement informants also indicated that most teachers understand about economic literacy and economic literacy most do not understand it well, and some even have never heard of economic literacy.

The Material of economic literacy has not applied thoroughly recognized that the majority of teachers $86 \%$ and the remaining $17 \%$ stated already implemented thoroughly. Differences in understanding of economic literacy cause differences in the application of economic literacy learning. Although not explicitly of economic literacy materials do not require the ability to behave economic competence for elementary students, but curriculum implicitly contains of economic literacy learning in social studies.

In practice teachers of social studies using reference books as a basis for preparing the basic competencies to be achieved and not look for material in accordance with the basic competencies to be achieved. Understanding of teachers of economic literacy oriented to package, so less developed and creatively to find the appropriate material. Books related to of economic literacy embodied in social studies and only a fraction of the material containing social studies of economic literacy learning.

In social studies reference book that has been observed to contain a little of economic literacy learning and not specific but only at particular chapter discusses the economy. This is supported by survey data that $48 \%$ of teachers stated that only part the chapter includes learning about of economic literacy, the remaining $52 \%$ stated already discussed about the economy though incomplete, supported by the information that the application of economic literacy in elementary education is done, however a little and not specifically and not structured, but only put as one of the themes in social studies.

The Economic literacy learning in primary schools do not exist in detail in the curriculum but some of the paste in social studies, it is less adapted to the practice in life. The Economic literacy learning use lecture method, discussion and administration tasks. The instructional media used is whiteboard, markers, images corresponding to the material being taught. The use of other media such as internet, newspaper clippings are directed to support cognitive ability and not to strengthen the cultivation of values.

The scoring system used by the teacher is a written test, assessment discussions and activities, whereas affective assessment using attitudinal scales, it is because it tends to use the conventional learning models

Although social studies teachers in Malang have not implemented economic literacy education seriously, but almost all teachers agree on need economic literacy education, for the majority of teachers (89\%) agree need economic literacy education. The informant said that the need to implement economic literacy in elementary students to strengthen the character of students, it can be concluded that economic literacy education is necessary for elementary students because it will strengthen the character of the students early age to change the traditional thinking such as: surrender provision by God.

The survey shows that $83 \%$ of teachers expressed their readiness if the program overall economic literacy learning applied in school despite the need to prepare and the remaining $17 \%$ is not ready, the majority of primary teachers need to teach economic literacy guidance for students to obtain a similar perception.

Economic literacy education is not explicitly in learning on elementary school, because it can not be denied that the learning should be applied detail for students, the elementary school teachers would be a burden, but as a noble heart Unsung Hero, the majority of them do not feel burdened to apply economic literacy education with the purpose to the good life in the future

\section{Discussion}

The findings in the previous section shows that until now the economic literacy learning on primary schools is not contained in detail in the subject, there is little published in social studies textbooks. The curriculum is not contains the economic literacy materials in depth. It is therefore made sense that the majority the teachers do not understand in detail of economic literacy, and require teachers get economic literacy materials in detail.

It supports the low economic literacy phenomena as published in the Media Indonesia (04/03/2011) that only $42.6 \%$ of economic teachers have good qualified. This leads to a low level economic literacy community. The low economic literacy will be impact on consumer attitudes for society. Another indication of 
the low level of economic literacy is a lot of fraud cases and victims wrapped in investment, the low spirit of people to save, excessive spending habits so hard to be a smart consumer.

The teachers agreed that the matter would be made in the form of learning fun with easy to understand language on elementary school, the teachers are ready to teach with curriculum contains material of economic literacy, this case because economic literacy, including educational characters that need to be given early because it will change the traditional thinking such as: resigned to giving god and any future majors can not be separated from economic activities

This is supported by the logic of economic literacy not only teaches how to react to a policy or ideas about the economic environment, but how to put this information into the appropriate context and evaluate it. Someone has the economic literacy will be able to analyze information to make the right financial decisions. And it also shows that the need to identify the relevant economic information. In other words, economic literacy will enable the person to become aware of the changes in economic activity.

Education has not been explicitly economic literacy learning in elementary school, because it is not denied that economic literacy will be applied toward the student elementary school teachers will be burdened, but because of his noble heart The unsung heroes, they are enthusiastic and not feel burdened to implement economic literacy education with the goal to the good life in the future students. The teacher states require training and support books.

\section{Conclusion}

Based on the results of research and discussion, it is concluded several things: 1) The lack of economic literacy curriculum in particular, but the material was only put in social studies 2) Some teachers have learned about economic literacy, but not in detail. 3) The lack of economic literacy instructional books and special details. 4) Teachers are ready to deliver learning to strengthen the character of economic literacy of students in the preparation of future life, though admittedly requires preparation materials are also books on economic literacy. It requires a book that is easy to understand and fun to read elementary school age children, for example: cartoon-based books

\section{References}

[1]. Antara news. Hanya 42,6 persen Guru Ekonomi Berkualitas baik. 2012. Baik.ht1 m.htm.

[2]. Gouws,D.G. 2009. Financial Literacy: an Interface Between Financial Information and Decsion makers in Organizations. Southern African Business Review Vol 13 No 2.

[3]. Jappelli.T. 2010. Economic Literacy: An International Comparation , No 2010/16

[4]. Kotte,D \& /witt R. 2011.Chance and Challenge: Assessing Economic Literacy . www.google-economic literacy.

[5]. Media Indonesia. 2011. Hanya 42,6 persen Guru ekonomi Berkualitas Baik. Edisi 3 April 2011.

[6]. Mathews, L.G. 1999. Promotin Economic Literacy: Ideas for Your Classroom. Paper prepared for the 1999 AAEA Annual meeteng Nashville. Tennessee.

[7]. Molem,C,S. 2007. Economic Information Literacy and the Development sub-Saharan African Countries. A Lead paper presented at the Sub-Saharan Regional Colloquium on Information Literacy. Organized by UNECA, Addis Ababa, Ethiopia form 29-31 March 2007.

[8]. Pos Kupang. 2010. Menabung sebagai sikap Hidup. Edisi 18 September 2010

[9]. Prugh Thomas (1995).”Natural Capital And Human Economic Survival” International Society for Ecological Economics, Solomon, MD, USA.

[10]. Uno,Hamzah.2007. Model Pembelajaran. Bumi Aksara. Jakarta.

[11]. Utami, Nunung N (2011). Analisis Investasi Sumber Daya Manusia dan Pertumbuhan Ekonomi (Kajian Kawasan Indonesia dan Negara Anggota ASEAN Lainnya).Dissertation - Universitas Negeri Malang.

[12]. Utami, Nunung N (2008). Perilaku Wirausaha Masyarakat Pesisir dalam Pengembangan Industri Pariwisata Bahari Pantai Selatan Jawa Timur.

[13]. Utami, Nunung N (2007), Kajian Pengembangan Kemandirian Usaha pada Kelompok Masyarakat Miskin Kota, , Jurnal AkuntansiBisnis \& Manajemen Vol 17 No:1, ISSN:0854-4190, Desember 2007”.

[14]. Www.google.co.id :Widyaiswara, Sugiyanta .(2008). Implementasi Model Pembelajaran Kooperatif Thing-Pair-Share (TPS) pada Pokok Bahasan Zat dan Wujudnya .

[15]. Wahjoedi,2008. Kekinian Pendidikan Ekonomi dan Bisnis dalam Menghadapi Tuntutan dan Tantangan Jaman. Makalah Seminar Nasional PPS UM, 2 Pebruari 2008.

[16]. Yunus, N,K. Y, Ishak, S \& Jalil, N.A. 2010. Economic Literacy Amongst the Secondary School Teachers in Perak Malaysia . Information Management and Business Review Vol 1 No 2, Dec 2010. 